\title{
Analysis of determinants of the inflow of foreign direct investment to Poland. Part II - research results ${ }^{1}$
}

Joanna Wyrwa, Ph.D., University of Zielona Góra, Faculty of Economics and Management, Poland, ORCID: 0000-0003-0837-6590.

\section{Introduction}

In recent years, foreign direct investment (FDI) has become a significant element of the Polish economy. Poland has seen a significant increase in FDI inflows, being currently one of the most important recipients of foreign capital from among the new EU member states. Poland has been relatively successful at confronting the global financial crises of the last decade - recording one of the highest economic growth rates in the European Union (EU), one of the lowest unemployment rates in the EU, and all this while avoiding "major financial turbulence" (SpotData 2018, p. 3). The favorable conditions for doing business in Poland, also highlighted by the Strategy for Responsible Development (Ministerstwo Funduszy i Polityki Regionalnej 2017), are reflected in the opinions of reputable international centers. Last year the World Bank published its Doing Business 2019 report, where Poland was among the countries with the best business conditions. Poland's relatively stable

1 The article was developed as part of the implementation of a research project co-financed by the Marshal's Office of Lubuskie Province in the framework of the competition Small Grants for Public Universities from Lubuskie Province. 
rank in this report is a sign that the reforms introduced in the last decade have been effective.

The dynamic change of Poland's economy over the years has given rise to entirely new conditions for economic development, also in the context of the inflow of foreign capital. An important element of FDI analysis is identifying the motives guiding foreign investors in the choice of a location to inject capital. This is especially important because it allows assessing the level of development of a country's economy. A review of research studies on factors determining the size of involvement of international enterprises in Poland shows that economic determinants play a key role in the process of choosing Poland as a place to locate capital in the form of direct investment. Among these, market and resource motives have been of major significance (Wilson, 1990, p. 29; Tatoglu and Glaiser, 1998, p. 214; Karaszewski, 2001, p. 274, 280; Johanson, 2006, p. 17; Bitzenis, 2007, pp. 83-111; Jaworek, 2013, pp. 59-63; Gorynia, Nowak, Trąpczyński and Wolniak, 2015, p. 94; Shukurov, 2016, p. 87). While market motives have remained equally relevant over time, there has been quite a noticeable evolution in the area of resources. In the initial period, their cost advantages dominated, i.e. efficiency determinants (mainly labor costs), but soon, quality determinants (qualifications, skills of employees, etc.) would gain increasing importance (Jaworek and Karaszewski, 2018, p. 45).

The changing nature of the size and structure of FDI over time justifies efforts, both theoretical and empirical, to clarify the determinants of these changes. This study builds on previous research and is devoted to the analysis of the main motives conditioning the inflow of foreign direct investment to Poland in the context of multidimensional causal analysis (Sroka, 2012). The main purpose of the article is to identify the factors determining the inflow of foreign direct investment to Poland based on empirical research. This is the second part of the series of studies, in which a summary of how FDI developed in Poland between 2010 and 2018 and the results of own research conducted using structural equation modeling (SEM) are presented. The determinants were assessed based on the results of the causal relationship existing between the scale of foreign direct investment inflow and selected macroeconomic parameters serving as explanatory variables. On the basis of theoretical knowledge and published research results in this area (Wyrwa, 2019, pp. 241247, 250-252), the relationship between FDI inflow to Poland and market size, labor costs as well as the quality and availability of workforce were analyzed. The article was prepared using the available statistical data of the United Nations Conference on Trade and Development (UNCTAD), the National Bank 
of Poland (NBP) and Poland's Central Statistical Office (GUS) regarding foreign investment flows in 2010-2018.

Due to the complexity (Dyduch, 2015) of the considered constructs determining the specifics of the research model, a decision was made to apply structural equation modeling as a method of testing hypotheses, which in turn had an impact on variable measurement methods (Światowiec-Szczepańska, 2015; Bedyńska and Książek, 2012). The method enables measuring and testing the directional relationship occurring between complex multi-dimensional theoretical constructs such as those assumed in the model. It is a method increasingly used for data analysis in economic sciences (West, Taylor, Wu, 2012; Sagan, 2015; Staniec, 2018). It should be noted, however, that SEM results are not always synonymous with those obtained using traditional statistical methods (Januszewski, 2011, p. 218).

\section{Foreign direct investment in Poland in $2010-2018$}

Analyzing the changes in the value of FDI inflows to Poland in 2010-2018², it can be seen that it was a period in which the role of FDI in the Polish economy evolved significantly (Wyrwa, 2018). The inflow of foreign direct investment has had a significant impact on the development of Poland's economy, leading to economic growth and embrace of innovation. Foreign-invested enterprises have been the driving force of exports and suppliers' demand while strengthening the position of enterprises in supply chains. Foreign-invested enterprises quickly increased their value and production efficiency. The FDI inflow was also a direct impulse to boost domestic demand and consumption, and to strengthen the role of the services sector in the economy. Foreign investment has been a source of positive externalities and at the same time provided competition to local enterprises across many industries. FDI, with its positive effects on supply and demand, has improved Poland's overall economic situation and economic potential. This was due both to the increased value of capital injected into the economy and the increased efficiency of factors of production owed to the implementation of investments and increasing productivity coupled with the spread of positive externalities (Czerniak, Blauth, Lipiński 2017, pp. 17-18; Adamowicz, 2019, pp. 231-232). The inflow of foreign direct investment to Poland between 2010 and 2018 is showed in table 1.

22010 was assumed as the lower limit for the time range of the analysis, due to the fact there was a significant increase in the value of FDI inflowing to Poland starting that year.

JOANNA WYRWA 
Table 1. Inflow of foreign direct investments to Poland in 2010-2018

\begin{tabular}{l|c|c|c|c|c|c|c|c|c}
\hline \multicolumn{1}{c|}{ Item } & 2010 & 2011 & 2012 & 2013 & 2014 & 2015 & 2016 & 2017 & 2018 \\
\hline $\begin{array}{l}\text { FDI inflow (in millions } \\
\text { of dollars) }\end{array}$ & 12796 & 15925 & 12424 & 2734 & 14269 & 15271 & 15690 & 9179 & 11476 \\
\hline $\begin{array}{l}\text { Dynamics index (pre- } \\
\text { vious year = 100) }\end{array}$ & 100.0 & 124.4 & 78.0 & 22.0 & 521.9 & 107.0 & 102.7 & 58.5 & 125.0 \\
\hline $\begin{array}{l}\text { Share in the global } \\
\text { FDI inflow in \% }\end{array}$ & 0.92 & 1.0 & 0.78 & 0.19 & 1.05 & 0.75 & 0.81 & 0.61 & 0.88 \\
\hline
\end{tabular}

Source: own study based on: World Investment Report from 2011-2019.

According to NBP data, foreign direct investment in Poland reached PLN 50.4 billion in 2018, accounting for approx. $2.5 \%$ of GDP (table 1). The net inflow of foreign direct investment to Poland increased by 45.3\% compared to 2017. In 2018, foreign direct investment targeted primarily entities involved in total services (PLN 26.2 billion), manufacturing (PLN 21.5 billion), wholesale and retail trade, including repair of motor vehicles and motorcycles (PLN 13.9 billion) and professional, scientific and technical activities (PLN 6.5 billion).

Table 2. Foreign direct investment transactions in Poland in 2010-2018 (in PLN million)

\begin{tabular}{c|c|c|c|c}
\hline Year & $\begin{array}{c}\text { Shares and other } \\
\text { forms of equity } \\
\text { participation }\end{array}$ & $\begin{array}{c}\text { Reinvestment of } \\
\text { profits }\end{array}$ & Debt instruments & Total \\
\hline 2010 & 12572.7 & 22447.8 & 6815.1 & 41835.6 \\
\hline 2011 & 9984.6 & 21326.5 & 29793.6 & 61104.0 \\
\hline 2012 & -11037.4 & 18579.8 & 12192.9 & 19734.9 \\
\hline 2013 & -23009.2 & 14732.2 & 16918.2 & 8641.2 \\
\hline 2014 & 13297.0 & 25939.5 & 5774.8 & 45011.3 \\
\hline 2015 & 21879.0 & 29145.1 & 6539.4 & 57563.4 \\
\hline 2016 & 7749.5 & 37295.4 & 16817.9 & 61862.8 \\
\hline 2017 & -3991.5 & 39048.7 & -391.9 & 34665.3 \\
\hline 2018 & 11150.0 & 37779.2 & 1443.2 & 50372.3 \\
\hline
\end{tabular}

Source: own study based on: NBP Reports from 2011-2018 
In the analyzed period, foreign direct investment inward position rose from PLN 639.1 billion in 2010 to PLN 859.1 billion in 2018 (table 3). This included liabilities arising from shares and other forms of equity participation and from debt instruments. The highest liabilities as at the end of 2018 were recorded for the Netherlands (PLN 183.4 billion), Germany (PLN 149.9 billion) and Luxembourg (PLN 122.1 billion). The largest amounts of liabilities were related to total services (PLN 506.2 billion), manufacturing (PLN 269.4 billion), financial and insurance activities (PLN 159.2 billion), and wholesale and retail trade, including repair of motor vehicles and motorcycles (PLN 114.2 billion).

Table 3. Balance of liabilities on account of foreign direct investments in Poland in the years 2010-2018 (in PLN million)

\begin{tabular}{c|c|c|c}
\hline Year & $\begin{array}{c}\text { Shares and other forms of } \\
\text { equity participation }\end{array}$ & Debt instruments (netto) & Total (netto) \\
\hline 2010 & 476538.3 & 162565.8 & 639104.1 \\
\hline 2011 & 481116.7 & 212988.3 & 694105.0 \\
\hline 2012 & 514421.1 & 214327.4 & 728749.2 \\
\hline 2013 & 548838.3 & 149989.1 & 741716.5 \\
\hline 2014 & 569116.5 & 172600.0 & 725551.5 \\
\hline 2015 & 543296.5 & 182255.0 & 788774.3 \\
\hline 2016 & 582603.7 & 206170.5 & 836842.4 \\
\hline 2017 & 639015.7 & 197826.7 & 859095.9 \\
\hline 2018 & 653010.1 & 206085.8 & 798.4 \\
\hline
\end{tabular}

Source: own study based on: NBP Reports from 2011-2018.

Direct investment income in 2018 broken down by economic activity of the direct investment enterprise was PLN 86.5 billion, with dividends amounting to PLN 39.4 billion, reinvested earnings - to PLN 37.7 billion, and income on debt (interest) - to PLN 9.3 billion. The highest income was reported for direct investors from the Netherlands (PLN 22.1 billion), Germany (PLN 16.7 billion) and Luxembourg (PLN 12.1 billion). 
The geographical structure of FDI inflow to Poland did not change much over the years (table 4). In 2018, the majority of capital came from EU countries (PLN 46840.1 million). According to the Polish Investment and Trade Agency (PAIH), in 2018, the group of foreign-invested companies comprised 24,780 entities. Foreign capital invested in Poland came from a total of 129 countries, with $90 \%$ from the EU.

Table 4. Ranking of the sources of FDI inflow to Poland in 2010-2018

\begin{tabular}{|c|c|c|c|c|c|c|c|c|c|}
\hline Rank & 2010 & 2011 & 2012 & 2013 & 2014 & 2015 & 2016 & 2017 & 2018 \\
\hline 1 & Jersey & $\begin{array}{l}\text { Luxem- } \\
\text { bourg }\end{array}$ & $\begin{array}{c}\text { Germa- } \\
\text { ny }\end{array}$ & $\begin{array}{l}\text { United } \\
\text { King- } \\
\text { dom }\end{array}$ & $\begin{array}{c}\text { Luxem- } \\
\text { bourg }\end{array}$ & $\begin{array}{c}\text { Nether- } \\
\text { lands }\end{array}$ & $\begin{array}{l}\text { Nether- } \\
\text { lands }\end{array}$ & $\begin{array}{c}\text { Germa- } \\
\text { ny }\end{array}$ & $\begin{array}{c}\text { Nether- } \\
\text { lands }\end{array}$ \\
\hline 2 & $\begin{array}{c}\text { Germa- } \\
\text { ny }\end{array}$ & Spain & France & $\begin{array}{c}\text { Germa- } \\
\text { ny }\end{array}$ & $\begin{array}{l}\text { Nether- } \\
\text { lands }\end{array}$ & $\begin{array}{c}\text { United } \\
\text { King- } \\
\text { dom }\end{array}$ & $\begin{array}{c}\text { Germa- } \\
\text { ny }\end{array}$ & $\begin{array}{c}\text { Luxem- } \\
\text { bourg }\end{array}$ & $\begin{array}{c}\text { Luxem- } \\
\text { bourg }\end{array}$ \\
\hline 3 & $\begin{array}{l}\text { Luxem- } \\
\text { bourg }\end{array}$ & $\begin{array}{l}\text { Germa- } \\
\text { ny }\end{array}$ & $\begin{array}{c}\text { United } \\
\text { King- } \\
\text { dom }\end{array}$ & $\begin{array}{c}\text { Switzer- } \\
\text { land }\end{array}$ & Francja & $\begin{array}{c}\text { Germa- } \\
\text { ny }\end{array}$ & $\begin{array}{l}\text { Luxem- } \\
\text { bourg }\end{array}$ & Cyprus & $\begin{array}{c}\text { Germa- } \\
\text { ny }\end{array}$ \\
\hline 4 & Cyprus & Sweden & Austria & Austria & Belgium & Spain & France & Austria & Malta \\
\hline 5 & Sweden & France & Cyprus & $\begin{array}{c}\text { Nether- } \\
\text { lands }\end{array}$ & Cyprus & Austria & Austria & $\begin{array}{c}\text { Hunga- } \\
\text { ry }\end{array}$ & Cyprus \\
\hline 6 & France & Cyprus & $\begin{array}{c}\text { Switzer- } \\
\text { land }\end{array}$ & Ireland & $\begin{array}{c}\text { Germa- } \\
\text { ny }\end{array}$ & $\begin{array}{c}\text { Luxem- } \\
\text { bourg }\end{array}$ & $\begin{array}{c}\text { United } \\
\text { King- } \\
\text { dom }\end{array}$ & $\begin{array}{c}\text { Czech } \\
\text { Repu- } \\
\text { blic }\end{array}$ & $\begin{array}{c}\text { Czech } \\
\text { Repu- } \\
\text { blic }\end{array}$ \\
\hline 7 & Italy & Grecja & Spain & $\begin{array}{c}\text { Norwe- } \\
\text { gia }\end{array}$ & Spain & Sweden & $\begin{array}{c}\text { Switzer- } \\
\text { land }\end{array}$ & Austria & $\begin{array}{c}\text { Switzer- } \\
\text { land }\end{array}$ \\
\hline 8 & Spain & Belgium & Belgium & $\begin{array}{l}\text { United } \\
\text { States }\end{array}$ & Ireland & Cyprus & Belgium & $\begin{array}{l}\text { United } \\
\text { States }\end{array}$ & Italy \\
\hline 9 & $\begin{array}{c}\text { United } \\
\text { King- } \\
\text { dom }\end{array}$ & $\begin{array}{c}\text { United } \\
\text { King- } \\
\text { dom }\end{array}$ & Italy & France & Italy & Belgium & Cyprus & Spain & Portugal \\
\hline 10 & Ireland & Curacao & Ireland & Spain & Malta & $\begin{array}{c}\text { Switzer- } \\
\text { land }\end{array}$ & Norway & $\begin{array}{c}\text { Switzer- } \\
\text { land }\end{array}$ & Belgium \\
\hline
\end{tabular}

Source: own study based on: National Bank of Poland (https://www.nbp.pl/home.aspx?f=/publikacje/zib/zib.html) 
According to World Investment Report ${ }^{3}$ in 2018, Poland was the sixth most promising country in the world for FDI (EY's Attractiveness Survey Europe, 2019, p. 11). The outlook for FDI inflow to Poland over the next years is optimistic. The scale of foreign direct investment still points to an upward trend, which partly reflects economic development and the increasing degree of Poland's integration with the world economy. During the last years, the number of projects and jobs as part of FDI projects has been systematically increasing. In 2018, foreign investors implemented a total of 272 projects in Poland. Compared to 2017, this number increased by 80 new projects, an increase of 38\% (EY's Attractiveness Survey Europe, 2019, p. 13).

According to the 2019 PAIiH Grant Thornton and HSBC study, 94\% of foreign investors who have located capital in Poland were satisfied with their decision and would reinvest. On a five-point scale, the investment climate in Poland scored 3.7, and $65 \%$ of respondents described the conditions for doing business in Poland as at least good. British companies were overall the most enthusiastic with an average of 4.5 points, followed by China (4.2 points), and then Denmark and Germany (3.8 points each). Poland's main advantage is its economic stability, domestic market size and the availability of materials and components.

The relatively high investment attractiveness of Poland is mainly due to favorable conditions in the area of traditional factors, in particular the country's stable political and legal situation, absorbent internal market, dynamic economic growth, labor market potential, degree of financial market development, exchange rate stability, low-wage labor costs and low business taxes. However, these advantages are being gradually undermined by the conditions constituting the investment climate. In this respect, the Polish economy fares rather poorly in the international context. This mainly concerns poor road and rail infrastructure, low clarity and consistency of legal regulations, administrative and nonadministrative procedures related to setting up a business, and high non-wage labor costs. Without addressing these issues, it will be very difficult for Poland to retain its leading position in Central and Eastern Europe and remain an attractive location for the inflow of foreign direct investments from around the world.

3 The report on European countries' investment attractiveness is prepared by the International Ernst \& Young Group and consists of two parts. The first concerns the scale of FDI in Europe - data collected as part of the EY European Investment Monitor. The second part relates to research on how foreign investors perceive individual European countries (EY's Attractiveness Survey Europe from 2014-2019). 


\section{Relationship analysis based on a structural equation model}

In the study, the structural equation method was used to analyze the impact of individual motives on FDI inflow to Poland ${ }^{4}$. The essence of the SEM method is to reflect the mutual relationships between directly unobservable, latent variables by using their observable (relevant) measurement indicators for this purpose. This allowed testing the hypotheses based on theoretical considerations about the relationships between individual variables, with respect to both their occurrence as well as their strength and direction. For the purposes of the study, a hypothetical SEM model was developed in which determinants of FDI inflow to Poland in 2010-2018 were looked at. The study ultimately answered the research question of which macroeconomic factors, and to what extent, determine FDI inflow to Poland. In the empirical part, the hypothesis was put forward that FDI inflow to Poland is the resultant of three factors: market size, labor costs, and the quality and availability of workforce.

At the first stage of modeling structural equations, the model had to be specified. In line with the general concept of modeling structural equations, the modelbuilding process began with a thorough analysis of relevant literature sources. At this stage, based on theory and findings from previous research, a model was built. When building the model, it was determined not only what variables would be included in it, but also the relationships between them. More than one variable was used for measurement, which helped minimize the estimation error and obtain a more complete and more accurate picture of the independent variables. The model is based on three latent exogenous variables describing the factors determining FDI inflow to Poland (market size, labor costs, quality and availability of workforce) and one latent endogenous variable, namely FDI inflow to Poland. All four variables are therefore latent variables. Each of the exogenous constructs has its own empirical argumentation. For the market size variable, these are the observable indicators: GDP (x1), GDP per capita (x2), population (x3); for labor costs, these are: gross average monthly salary (x4), labor productivity per one employee (x5), employment-related costs (x6); and finally for

4 The structural equation model is defined as a set of statistical procedures and tools for measuring causal relationships in empirical scientific research. The SEM methodology allows for simultaneous consideration of relationships between independent and dependent as well as measurable (observable) and unobservable (latent) variables. In addition, the model may also account for potential measurement errors across observable variables, estimate and test variance and co-variance between variables, plus study direct and indirect relationships between them (Pearl, 2000). 
quality and availability of workforce, these are: number of students per 10,000 local residents ( $x 7)$, share of R\&D employees in total employees (x8), unemployment rate $(x 9)$. All these indicators constituted research material ordered within an empirical data matrix. Similarly, for the endogenous FDI inflow construct, the observable indicators are: number of foreign-invested enterprises in a given year (y1) and share capital value at the disposal of foreign-invested companies (y2). The essence of the SEM method is to reflect the mutual relationships between directly unobservable, latent variables by using their observable (relevant) measurement indicators for this purpose.

The model distinguishes the internal path structure describing the causeeffect relationships between unobservable variables as well as four measurement models characterizing the relationship between the latent variables and their observed indicators. Using the model, the loading values of individual factors shaping the latent variables can be calculated and the cause-effect relationships between them can be determined.

To compare the correlation strength of all variables in the model, the standardized values of structural parameter assessments were used. The diagram of the relationships between the variables in the estimated model is shown in figure 1.

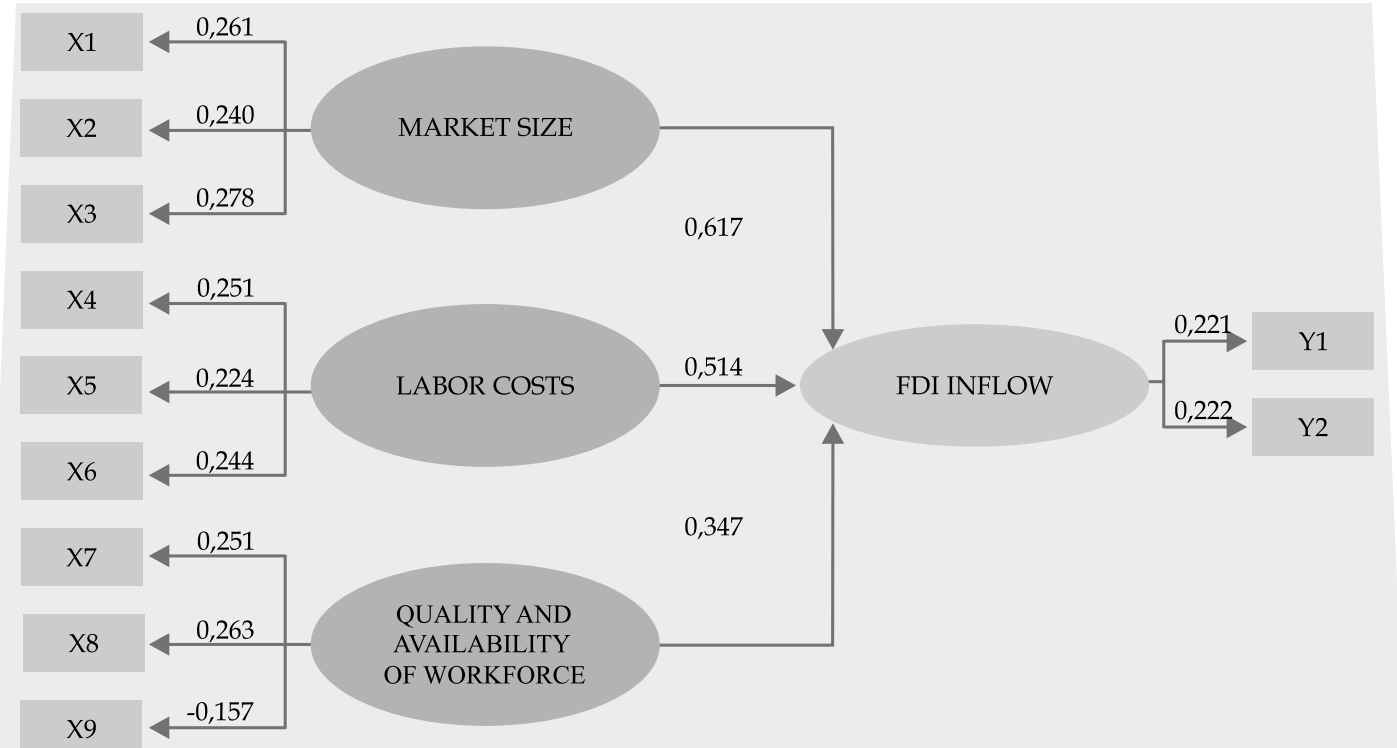

Figure 1. Path diagram of the model with structural parameter assessments

Source: own study 
Subsequently, the model was identified by estimating path parameters values. It was checked whether the basic model identification rule, the t-rule, was met. The t-rule assumes that the number of parameters to be determined should be less than or equal to the number of unique values in the covariance matrix.

In the next stage, model parameters were estimated. In structural equation modeling, this consists in determining their values so that the postulated model can best reproduce the observed covariance matrix. To this end, the maximum likelihood (ML) method was used ${ }^{5}$. It requires meeting the assumption of the multivariate normality of observable variables.

The choice of the maximum likelihood method as a function of divergence was preceded by testing the linearity of relationships between the variables and the normality of distributions. The values of asymmetry and kurtosis coefficients allow for using this method as an estimator of the model. The results of model estimation using the maximum likelihood method are shown in table 5.

Table 5. Assessment of path model parameters

\begin{tabular}{|c|c|c|c|c|}
\hline Kierunek wpływu & $\begin{array}{l}\text { Wartość } \\
\text { parametru }\end{array}$ & $\begin{array}{l}\text { Bląd stan- } \\
\text { dardowy }\end{array}$ & $\mathrm{T}$ & $\mathbf{p}$ \\
\hline MARKET SIZE $\rightarrow$ GDP & 0,261 & 0,048 & 5,477 & $<0,001$ \\
\hline MARKET SIZE $\rightarrow$ GDP PER CAPITA & 0,240 & 0,049 & 4,906 & $<0,001$ \\
\hline MARKET SIZE $\rightarrow$ POPULATION & 0,278 & 0,056 & 4,978 & $<0,001$ \\
\hline $\begin{array}{l}\text { LABOR COSTS } \rightarrow \text { AVERAGE MONTHLY GROSS } \\
\text { WAGE }\end{array}$ & 0,251 & 0,046 & 5,405 & $<0,001$ \\
\hline $\begin{array}{l}\text { LABOR COSTS } \rightarrow \text { LABOR PRODUCTIVITY PER } \\
\text { ONE EMPLOYEE }\end{array}$ & 0,224 & 0,055 & 4,095 & $<0,001$ \\
\hline $\begin{array}{l}\text { LABOR COSTS } \rightarrow \text { COMPENSATION OF EMPLOY- } \\
\text { EES }\end{array}$ & 0,244 & 0,053 & 4,630 & $<0,001$ \\
\hline $\begin{array}{l}\text { QUALITY AND AVAILABILITY OF WORKFORCE } \\
\rightarrow \text { NUMBER OF STUDENTS PER 10,000 RESIDENTS } \\
\text { IN A REGION }\end{array}$ & 0,251 & 0,055 & 4,529 & $<0,001$ \\
\hline $\begin{array}{l}\text { QUALITY AND AVAILABILITY OF WORKFORCE } \\
\rightarrow \text { SHARE OF R\&D EMPLOYEES IN TOTAL EM- } \\
\text { PLOYEES }\end{array}$ & 0,263 & 0,048 & 5,477 & $<0,001$ \\
\hline
\end{tabular}

5 Considering individual estimation methods in modeling structural equations, it should be noted that the maximum likelihood method is most often used. 


\begin{tabular}{|c|c|c|c|c|}
\hline $\begin{array}{l}\text { QUALITY AND AVAILABILITY OF WORKFORCE } \\
\rightarrow \text { UNEMPLOYMENT RATE }\end{array}$ & $-0,157$ & 0,062 & $-2,535$ & 0,011 \\
\hline $\begin{array}{l}\text { FDI INFLOW } \rightarrow \text { THE NUMBER OF ACTIVE } \\
\text { FOREIGN-INVESTED ENTERPRISES IN A GIVEN } \\
\text { YEAR }\end{array}$ & 0,221 & 0,000 & 35,261 & $<0,001$ \\
\hline $\begin{array}{l}\text { FDI INFLOW } \rightarrow \text { THE VALUE OF THE SHARE CAP- } \\
\text { ITAL AT THE DISPOSAL OF FOREIGN-INVESTED } \\
\text { ENTERPRISES }\end{array}$ & 0,222 & 0,008 & 29,233 & $<0,001$ \\
\hline MARKET SIZE $\rightarrow$ FDI INFLOW & 0,617 & 0,134 & 4,605 & $<0,001$ \\
\hline LABOR COSTS $\rightarrow$ FDI INFLOW & 0,514 & 0,119 & 4,331 & $<0,001$ \\
\hline $\begin{array}{l}\text { QUALITY AND AVAILABILITY OF WORKFORCE } \\
\rightarrow \text { FDI INFLOW }\end{array}$ & 0,347 & 0,066 & 5,268 & $<0,001$ \\
\hline
\end{tabular}

Source: own research results.

Analyzing the obtained parameter assessments for the relationship between the latent exogenous variable market size and its dummy variables indicates that population is more important for FDI inflow than GDP. In what concerns the latent exogenous variable labor costs, the average monthly salary, labor productivity and employment-related costs all play very much the same role. Analyzing the relationship between the latent exogenous variable quality and availability of workforce and its dummy variables, it was noted that the greatest importance should be attributed to the share of $R \& D$ employees in total employees. The relationship between the latent endogenous variable FDI inflow and its dummy variables should also be interpreted positively. These variables significantly describe the latent variable. Most importantly however from the perspective of the article, the impact of the three latent exogenous variables on the endogenous FDI inflow variable was determined. In view of the main modeling problem, it can be said that market size and labor costs had a significant impact on FDI inflow. Modeling results for the relationship between quality and availability of workforce and FDI inflow point to a weaker link between these variables than in the relationship between FDI inflow and both market size and labor costs. It should therefore be concluded that market size and labor costs are more important than manpower resources.

After the estimation process, testing of the model was carried out, during which a reasonableness test for the estimated parameters was performed, followed by a verification of the model's goodness of fit. The degree of fit of the theoretical 
model to data was assessed on the basis of a number of measures, among which absolute measures (GFI, AGFI, SRMR) and relative measures (comparison with alternative models - NFI, NNFI, CFI) were distinguished.

A general chi-square test was one of the first measures of model fit, where the lower the value of the test statistics, the better the fit of the model. The probability threshold is normally set at 0.05 . The chi-square test's sensitivity to sample size meant that other alternative fit indicators were used.

The next measure was the GFI (goodness-of-fit index) analogous to the regression determination coefficient. It belongs to the so-called absolute-fit measures and is largely independent of sample size. This parameter informs about the percentage of variance in the observed matrix which the postulated model explains. 0.95 is usually assumed to be satisfactory. There is also an adjusted version of this index, the AGFI (adjusted goodness-of-fit index), which is corrected for the number of degrees of freedom. It is a measure analogous to the adjusted coefficient of determination in regression models, which takes into account the number of degrees of freedom relative to the number of variables. The higher the $d f$ number, the better the model. Values above 0.9 mean the model is acceptable, above 0.95 - satisfactory, and 1 - perfect fit.

The next measure of fit was the standardized root mean squared residual (SRMR), which assumes assessing the overall fit level of the SEM model (from 0 to 1) based on the resulting residues as a result of comparing the empirical against the reconstituted matrix. The higher the value of the measure, or in other words the larger the residue generated by the postulated model, the less fit it is considered to be. In this case, the threshold not to be exceeded is 0.1. Because the index itself reflects the level of "fitness mediocrity" in a model, interpretation assumes that zero values indicate a perfect fit while higher values indicate a worse fit, but - as Hu and Bentler (1999) rightly point out - in social research practice, 0.08 already proves the adequacy of the considered model. It is also worth noting that an important premise for using the SRMR index is its simplicity in interpreting the result, which expresses the absolute size of the mean residual in units of correlation coefficient.

Additionally, the SEM model's degree of fit was assessed using measures in which the estimated model is compared with the base model. This is a very important group of comparative indicators that determine the degree to which a given model is better than the zero model, that is one without latent variables and with the only relationships existing between observable variables. In this way, the degrees of freedom required to achieve the right fit of the model with the data are revealed. The results for the tested model are shown in table 6. 
Table 6. Model fitness statistics

\begin{tabular}{l|c}
\hline \multicolumn{1}{c|}{ Goodness-of-fit measures } & Score \\
\hline ML Chi-Square & 253.712 \\
\hline Degrees of Freedom & 41.000 \\
\hline p-level & $<0.001$ \\
\hline GFI & 0.441 \\
\hline AGFI & 0.100 \\
\hline SRMR & 0.556 \\
\hline NFI & 0.493 \\
\hline NNFI & 0.357 \\
\hline CFI & 0.523 \\
\hline \multicolumn{2}{c}{ Source: own research results }
\end{tabular}

The measures confirm the relatively low fit of the model to the data. Model parameter estimates showed that all of the obtained path coefficients were statistically significant $(\mathrm{p}<0.01)$. Market size and labor costs appear to have the greatest impact on FDI inflow. However, the estimated model turned out to be unsatisfactory. Estimated assessments for the goodness of fit of the model should be considered unsatisfactory. Although maximum likelihood (ML) is highly significant $(\mathrm{p}<0.01)$, meaning the model as a whole is significant, the goodness-of-fit measures are at either low or average levels. Insufficient model fitness was indicated by the adopted parameters: the GFI showed that only $44.1 \%$ of the actual covariance is explained by the model, while the AGFI also recorded a relatively low value; the SRMR, meanwhile, exceeded acceptable values.

The postulated model is not the best but it is not the worst either. Favorable to it are the estimated parameter values which showed a high level of significance in most paths. However, due to the insufficient goodness-of-fit overall, the model needs to be modified. The most advanced form of model modification is its transformation according to a theory that is alternative to the one previously adopted. Another way is to reorganize the model based on the results of significance tests for the variables. The proposed treatment will most likely improve the value of the goodness-of-fit coefficients. 
The completed research is not free from classical limitations. The drawbacks of structural equation modeling include the specific "hermeticity" of implementing this procedure in statistical software, meaning the lack of insight into the progressive implementation of the algorithm (Januszewski, 2011). Hence the great difficulty in identifying directions for modifying the models with a view to obtaining the best fit against the data. Another potential limitation of the research procedure is the fact that the model did not include the mediator role for the endogenous latent variable and therefore only the most important direct impacts were tested. In addition, the limitations of the study include making the formulation of the model hypothesis dependent on the scope of data provided by the Polish Central Statistical Office.

\section{Conclusion}

The internationalization process currently taking place in Poland means that more dynamic capital flows to the Polish economy in the form of FDI can be observed. Based on own research and publications by other authors (cf. Żak, 2019), it can be stated that the investment position of the Polish economy is changing very slowly but steadily. Increasingly, we are dealing with the inflow of more capital-intensive and technologically advanced FDI.

The article presents the results of own research, the scope of which covered the recognition of motives for FDI in Poland between 2010 and 2018, using to this end the SEM methodology. For the needs of the study, a hypothetical SEM model was created, where - in line with the assumed objective of the article - determinants of FDI inflow to Poland were considered. Model estimation and verification allowed identifying the distinguished factors, but it failed to confirm the significant impact of selected motives on FDI inflow to Poland. The results of the structural equation model indicate that market size and labor costs were the two most important factors for FDI inflow to Poland. The direction of impact of both variables is in line with expectations, meaning these factors may indeed translate into FDI growth in Poland. However, the analysis is not exhaustive. Having said all that, the study provided a number of findings which can be used to build a more accurate theoretical model, and as such, it has paved the way for further research. To formulate detailed conclusions, in-depth research going beyond the model adopted in this study must be conducted. 


\section{Summary}

Analysis of determinants of the inflow of foreign direct investment to Poland. Part II - research results

This study contains an analysis of the main determinants of the inflow of foreign direct investment to Poland. This article is devoted to the analysis of the main motives determining the inflow of foreign direct investment to Poland. It is the second part of the series and presents the scale and dynamics of FDI inflow to Poland between 2010 and 2018, as well as the results of own research carried out using structural equation modeling. This study focused on determining the cause-and-effect relationship between the scale of inflow of foreign direct investment and selected macroeconomic parameters of the economy. Based on the theories and results from previous research, a model was developed in which the variables and the nature of their relationship were determined. The model is based on four latent exogenous variables describing FDI determinants and one latent endogenous variable describing FDI inflow. In the article, structural equation modeling was indicated as a method for analyzing the factors conditioning the inflow of foreign direct investment. The proposed research concept will allow supplementing and extending the analysis of FDI determinants in Poland.

Keywords: foreign direct investment; FDI in Poland; structural equation modeling (SEM).

\section{Streszczenie}

Analiza uwarunkowań napływu bezpośrednich inwestycji zagranicznych do Polski. Część II - wyniki badań

Artykuł poświęcony jest analizie głównych motywów warunkujących napływ zagranicznych inwestycji bezpośrednich do Polski. Stanowi drugą część cyklu i przedstawia skalę oraz dynamikę kształtowania się BIZ w Polsce w latach 20102018, a także wyniki badań własnych przeprowadzonych przy wykorzystaniu metody modelowania równań strukturalnych. Badania koncentrowały się na określeniu związku przyczynowoskutkowego między skalą napływu bezpośrednich inwestycji zagranicznych i wybranymi parametrami makroekonomicznymi 
gospodarki. Na podstawie teorii oraz wyników dotychczasowych badań zbudowano model, w którym określono zmienne i charakter relacji międ zy nimi. Model bazuje na czterech ukrytych zmiennych egzogenicznych opisujących determinanty BIZ oraz jednej ukrytej zmiennej endogenicznej, tj. napływ BIZ. W artykule do analizy czynników warunkujących napływ bezpośrednich inwestycji zagranicznych wskazano metodę równań strukturalnych. Zaproponowana koncepcja badawcza pozwoli na uzupełnienie i rozszerzenie analiz dotyczących determinant BIZ w Polsce.

\section{Słowa}

kluczowe: bezpośrednie inwestycje zagraniczne; BIZ w Polsce; modelowanie równań strukturalnych.

JEL

Classification: F21; F23; F62; R15

\section{References}

1. Adamowicz, M. (2019). Bezpośrednie inwestycje zagraniczne w regionie peryferyjnym na przykładzie województwa lubelskiego [Direct foreign investment in peripheral regions: a case study of the Lublin Voivodship]. Economic and Regional Studies, Vol. 12, No. 3, pp. 223-241. DOI: https:/ / doi. org/10.2478/ers-2019-0021.

2. Bedyńska, S. and Książek, M., (2012). Statystyczny drogowskaz: praktyczny przewodnik wykorzystania modeli regresji oraz równan strukturalnych. Warszawa: Wydawnictwo Akademickie SEDNO.

3. Bitzenis, A. (2007). Determinants of Foreign Direct Investment: Evidence from Multinationals in the Post-crisis Era of Bulgaria in the Late 1990s'. Southeast European and Black Sea Studies, Vol. 7, No. 1, pp. 83-111. DOI: https:// doi.org/10.1080/14683850701189352.

4. Czerniak, A., Blauth, K. and Lipiński, Ł. (2017). Co przyniosty inwestycje zagraniczne. Wpływ na gospodarke Polski w ostatnim ćwierćwieczu. Polityka Insight Research.

5. Dyduch, W. (2015). Ilościowe badanie i operacjonalizacja zjawisk w naukach o zarządzaniu. In: Czakon, W. (ed.), Podstawy metodologii badań naukowych o zarządzaniu (pp. 306-330). Warszawa: Wolters Kluwer Business.

6. EY's Attractiveness Survey Europe (2015). Comeback time.

7. EY's Attractiveness Survey Europe (2016). How can Europe's investors turn resilience into growth? 
8. EY's Attractiveness Survey Europe (2017). Investors vote "remain" in Europe.

9. EY's Attractiveness Survey Europe (2018). Game changers.

10. EY's Attractiveness Survey Europe (2019). How can Europe raise its game?

11. EY's Attractiveness Survey Europe (2014). Back in the game.

12. Gorynia, M., Nowak, J., Trąpczyński, P. and Wolniak, R. (2015). Does outward FDI by Polish multinationals support existing theory? Findings from a quantitative study. Economic and Business Review, Vol. 1(15), No. (4), pp. 84-101. DOI: 10.18559/ebr.2015.4.6.

13. Hu, L.-T. and Bentler, P.M. (1999). Cutoff criteria for fit indexes in covariance structure analysis: Conventional criteria versus new alternatives. Structural Equation Modeling, Vol. 6, Iss. 1, pp. 1-55. DOI: 10.1080/10705519909540118.

14. Januszewski, A. (2011). Modele równań strukturalnych w metodologii badań psychologicznych. Problematyka przyczynowości w modelach strukturalnych i dopuszczalność modelu. In: Gorbaniuk, O., KostrubiecWojtachnio, B., Musiał, D., Wiechetek, M., Błachnio, A., Przepiórka, A. (eds.), Studia z Psychologii w KUL (pp. 213-245). Lublin: Wydawnictwo KUL.

15. Jaworek, M. (2013). Stymulanty i destymulanty aktywności inwestycyjnej polskich przedsiębiorstw za granicą. In: Karaszewski, W. (ed.), Aktywność inwestycyjna polskich przedsiębiorstw za granica - czynniki i skutki. Warszawa: Polskie Wydawnictwo Ekonomiczne.

16. Jaworek, M. and Karaszewski, W. (2018). Ewolucja determinant podejmowania bezpośrednich inwestycji zagranicznych $\mathrm{w}$ Polsce [Evolution of the Determinants of Undertaking Foreign Direct Investments in Poland]. Kwartalnik Naukowy Uczelni Vistula, No. 2(56), pp. 42-59.

17. Johnson, A. (2006). FDI inflows to the Transition Economies in Eastern Europe: Magnitude and Determinants. Working Paper Series in Economics and Institutions of Innovation, No. 59. Royal Institute of Technology, CESIS - Centre of Excellence for Science and Innovation Studies. https://static. sys.kth.se/itm/wp/cesis/cesiswp59.pdf. (20.12. 2019 - access date).

18. Karaszewski, W. (2001). Przedsiębiorstwa z udziatem kapitatu zagranicznego w Polsce w latach 1990-1999 (miejsce w gospodarce kraju, czynniki i perspektywy rozwojowe). Torun: Wydawnictwo Naukowe Uniwersytetu Mikołaja Kopernika.

19. Ministerstwo Funduszy i Polityki Regionalnej (2017). The Strategy for Responsible Development for the period up to 2020 (including the perspective up to 2030). https://www.gov.pl/web/fundusze-regiony/informacje-ostrategii-na-rzecz-odpowiedzialnego-rozwoju (20.12. 2019 - access date).

20. Pearl, J. (2000). Causality: Models, Reasoning, and Inference. New York: Cambridge University Press. 
21. Polską Agencją Inwestycji i Handlu (2019). Investment climate in Poland 2018.

22. Sagan, A. (2015). Modele PLS-PM i ich zastosowania w predykcji i wyjaśnianiu zjawisk ekonomicznych [PLS-PM Model and its Application in Explanation and Prediction of Economic Phenomena]. Zeszyty Naukowe Uniwersytetu Szczecińskiego. Studia i Prace Wydziatu Nauk Ekonomicznych i Zarządzania, No. 39, Vol. 2, pp. 127-138.

23. Shukurov, S. (2016). Determinants of FDI in Transition Economies: The Case of CIS Countries. Journal of International and Global Economic Studies, Vol. 9, Iss. 1, pp. 75-94.

24. SpotData (2018). Wielki awans przemysłowy. Jak rośnie rola przemysłu w polskiej gospodarce i globalnych łańcuchach dostaw. https://spotdata. $\mathrm{pl} /$ research/download/57 (20.12. 2019 - access date).

25. Sroka, W. (2012). Zastosowanie modeli przyczynowo-skutkowych do oceny czynników sukcesu gospodarstw rolniczych - porównanie wybranych metod [Application of Cause and Effect Models to Evaluate Farms' Success Factors - the Comparison of Selected Methods]. Zagadnienia Ekonomiki Rolnej, Vol. 332, No. 3, pp. 28-42.

26. Staniec, I. (2018). Modelowanie równań strukturalnych w naukach o zarządzaniu [Use of structural equation modeling in management research], Organizacja i Kierowanie, No. 2, pp. 65-77.

27. Światowiec-Szczepańska, J. (2015). Zaawansowane testowanie model badawczych. In: Czakon, W. (ed.), Podstawy metodologii badań naukowych o zarzadzaniu (pp. 351-379). Warszawa: Wolters Kluwer Business.

28. Tatoglu, E. and Glaister, K.W. (1998). An analysis of motives for western FDI in Turkey. International Business Review, Vol. 7, Iss. 2, pp. 203-230.

29. West, S.G., Taylor, A.B. and Wu, W. (2012). Model fit and model selection in structural equation modeling. In: Hoyle, R.H. (ed.), Handbook of structural equation modeling (pp. 209-231). New York: The Guilford Press.

30. Wilson, M. (1990). Empirical evidence of the use of a framework of risk and return in capital budgeting for foreign direct investment. Managerial Finance, Vol. 16 No. 2, pp. 25-34. DOI: https:// doi.org/10.1108/eb013642.

31. World Investment Report. Investing in a Low-Carbon Economy (2010). New York and Geneva: United Nations Publication.

32. World Investment Report. Investing in tThe SDGs: an Action Plan (2014). New York and Geneva: United Nations Publication.

33. World Investment Report. Investment and New Industrial Policies (2018). New York and Geneva: United Nations Publication.

34. World Investment Report. Investment and the Digital Economy (2017). New York and Geneva: United Nations Publication.

35. World Investment Report. Investor Nationality: Policy Challenges (2016). New York and Geneva: United Nations Publication. 
36. World Investment Report. Non-Equity Modes of International Production and Development (2011). New York and Geneva: United Nations Publication.

37. World Investment Report. Reforming International Investment Governance (2015). New York and Geneva: United Nations Publication.

38. World Investment Report. Special economic zones (2019). New York: United Nations Publication.

39. World Investment Report. Towards a New Generationo Investment Policies (2012). New York and Geneva: United Nations Publication.

40. Wyrwa, J. (2018). Foreign Direct Investments And Poland's Economic Development - Current Situation And Development Prospects. Acta Oeconomica Universitatis Selye. International Scientific Journal, Vol. 7, No. 2, pp. 188-200.

41. Wyrwa, J. (2019). Analysis of determinants of the inflow of foreign direct investment to Poland. Part I - theoretical considerations. Management, Vol. 23, Iss. 2, pp. 238-262. DOI: https:// doi.org/10.2478/manment-2019-0029.

42. Żak, K. (2019). Bezpośrednie inwestycje zagraniczne polskich przedsiębiorstw: istota, determinanty i główne tendencje [Foreign Direct Investments of Polish Enterprises: Concept, Determinants and Main Trends]. Studia Ekonomiczne / Uniwersytet Ekonomiczny w Katowicach. Zarzadzanie, Vol. 17, No. 380, pp. 7-16. 